\title{
The COVID-19 Experience: Features of Culture and Belonging in the Context of Peoples Native to a Country and Migrants
}

\author{
Natalia V. Grishina ${ }^{\mathrm{a}^{*}}$, Polina V. Lupulyak $\mathrm{k}^{\mathrm{a}, \mathrm{b}}$ \\ ${ }^{a}$ Saint Petersburg State University, Saint-Petersburg, Russia \\ ${ }^{b}$ MiMarbella Project, Málaga, Spain
}

*Corresponding author. E-mail: n.v.grishina@spbu.ru

Background. COVID-19 has revealed the diversity of cultural characteristics and mentalities of different countries: every people living through the pandemic interprets the means of overcoming the crisis in their own way, in accordance with their historical experience and cultural traditions.

Objective. The purpose of this study (April 2 - May 2, 2020) was to identify the influence of cultural factors and the context of residence (living in their own country or in another culture as a migrant) on how people perceive and experience a pandemic.

Design. The study involved 605 people: 402 Russian-speaking respondents (221 migrants living outside their countries) and 203 representatives of other cultures (165 Spaniards and 38 migrants from different countries). The main research method was a survey using a specially prepared questionnaire (in four languages - Spanish, English, German, and Russian).

Results. Cultural factors had a strong influence on how a people experienced a pandemic. Respondents from European and other cultures (non Russian speakers) were very intolerant of dissent in the fight against the pandemic; showed an increase in patriotism; and demonstrated increased readiness for an operational response to the situation through a change of activity. Russianspeaking respondents showed great loyalty to different positions and different behaviors during pandemic situation; expressed the desire to wait out the pandemic and quickly return to their usual way of life; their main preventive measure was self-isolation, which was considered an opportunity for the development of something new. The perception of a pandemic by migrants differed from its perception by the native population.

Conclusion. Common to all representatives of the international sample were the ideas of necessary international cooperation and universal responsibility to overcome the pandemic. But the cultural factors and having a migrant's status had a strong influence on the perception and experience of the pandemic, which depends on the mentality and historical experience in different countries.
Keywords:

COVID-19;

perception and experience of pandemic situation; ethnopsychology; cultural features; migrant status 


\section{Introduction}

Over the past decades, the processes of globalization have affected not only economics and politics, but they have also led to the blurring of cultural boundaries between different communities, and even homogenization of many features of people's daily life. To a large extent, migration processes themselves contributed to this, as the scale of migration over the past half century has become extremely widespread: by 2017, the number of migrants in the world amounted to almost 260 million people (United Nations [UN], Migration). The tasks of regulating the processes of migration and assistance to immigrants are a part of government programs in many countries around the world.

However, the COVID-19 pandemic has forced many countries to re-designate their border policies, and also revealed the different characteristics of the culture and mentality of each country. The threat of the spread of the virus has forced residents of different countries to respond to a rapid wave of infections, and it turns out that every people living in a pandemic and quarantine situation interprets the means of overcoming the crisis differently, in accordance with their specific mentality, historical experience, and cultural traditions.

Modern culture is characterized by contradictory trends on ethnic processes. On the one hand, the processes of globalization have led to the melding of material and spiritual culture of different social communities; on the other hand (as it has turned out), globalization itself, by intensifying contacts between cultures, has contributed to the strengthening of ethnic attitudes and ethnic identity (the term "ethnic revival" can be found in the scientific literature these days).

According to experts, among the many features that differentiate ethnic groups and mark group boundaries, the main role is played by features that reflect cultural distinctiveness. Culture is the main factor underlying interethnic psychological differences (Stefanenko, 2014). At the same time, culture in ethnopsychology, in accordance with the classical approach of H. Triandis, is considered primarily subjective - a set of common ideas, attitudes, and beliefs about their community. Cultural features have a strong connection to a community's traditions and historical experience.

The strengthening of ethnic self-awareness and ethnic identity is significantly associated with the intensification of cross-cultural contacts, including the powerful migration flows that have reached an unprecedented scale in recent decades. The modern humanitarian literature contains a huge number of studies about the experience of migrants, the difficulties they have adapting in a new cultural context, and the factors that contribute to their successful intercultural adaptation. The models and stages of the adaptation process are described in particular in the works of J. Berry.

The pandemic situation has led to a transformation of people's habitual life space, including limiting their mobility to their immediate environment. It is weakening, and often making impossible, the ability to communicate outside of one's group. The pandemic is associated with various threats to life, health, and social and psychological well-being. It is also potentially capable of intensifying a collective and individual consciousness of the need to deal with threats to a group's safety, including actualization of feelings of "we-they" and "ingroup-outgroup." In this 
regard, the pandemic situation provides a unique opportunity to study the psychology of migrants.

This study is based on the interaction of the traditions of ethnic psychology and migrant psychology; it combines these two areas in a single original context, dedicated to analyzing the impact of factors of ethnicity and migrant status on the reaction of an unprecedented global crisis - the COVID-19 pandemic.

The aim of our previous study (Lupulyak \& Grishina, 2020) was to study the motivations for migration and the self-awareness of a migrant in a new life context. A comparative analysis of different groups of migrants revealed significant differences between Russian-speaking migrants and migrants from other countries living in Spain. They specifically related to the migrants' motivations for deciding to change their country of residence: about a third of Russian-speaking migrants indicated the interests of relatives as the most important factor in their decision, while this motivation was not typical for migrants from other countries. At the same time, Russian-speaking migrants (almost 60\%) said that they experienced difficulties living in their new country (unlike almost the same percentage of migrants from other countries who said they did not experience any difficulties). In particular, they expressed having problems with language (40\%, unlike $20 \%$ of migrants from other countries).

One potential factor in migrants' negative self-awareness of being in a new country is that their motivation for moving was associated with the desire to get away from the difficulties of their previous life situation and hopes for better conditions in a new life context. At the same time, a group of Russian-speaking participants in the study was characterized by the recognition of the positive potential of migration as a change in human life (62\%), while respondents from other cultures assessed their migration in more restrained tones (a positive assessment was given by only $24 \%$ of respondents) (Lupulyak \& Grishina, 2020).

The results of that study suggested that a pandemic that has changed people's lives (by quarantine, isolation, disrupting familiar activities and forms of communication, anxiety for the future, etc.) will have different effects on people belonging to different cultural contexts. The tasks of this current work were based on those differences and included identifying the similarities and differences in groups' opinions between Russian-speaking respondents and respondents from other cultures, people native to a country, and migrants, as well as analyzing the positions where there is a tendency for the coincidence or convergence of opinions between the Russian-speaking and another migrants.

The purpose of this study, which was conducted from April 2 to May 2, 2020, was to identify the influence of cultural factors and the context of residence (living in their own country or in another culture in the status of a migrant) on how people perceive and experience a pandemic situation.

The development of this issue is very relevant for two main reasons: first, it will provide an impetus for further study of the impact of ethnic characteristics on coping with crisis and extreme situations, as well as for a deeper study of the psychology of migrants. Secondly, it allows us to actively apply the data obtained in various spheres of social and political life, in order to optimize operational interaction between a state and a citizen in extreme and/or crisis situations. 
Understanding the original components of the "ethnic matrix," especially now, can be very useful for government agencies. In the context of the pandemic crisis, governments create solutions that are aimed at changing the lifestyles of the population. Understanding the ethnic matrix will allow them to minimize the negative public perception of their policies by creating a discourse and social advertising which will appeal to the values of particular groups of the population, either people native to a country or migrants.

\section{Methods}

\section{Participants}

This study involved 605 people from 18 to 80 years old. Group of Russian-speaking respondents (402 participants) consists of two subgroups: (1) individuals who are at the time of the survey in their countries of birth and permanent residence (Russian Federation or countries of the post-Soviet bloc: Ukraine, Belarus, the Baltic States, etc.) - 181 participants, who are classified as "native population" when interpreting the results; (2) persons with the status of migrants in countries of residence that are not countries of their origin -221 participants (in Spain -186 respondents, in other countries -35 respondents). Of the Russian-speaking respondents, 309 respondents were women and 93 participants were men; $73.1 \%$ of all respondents were $30-55$ years old, and $17.4 \%$ were $56-80$ years old.

The rest of the sample was comprised of 203 participants. It consists of two subgroups: (1) 165 Spaniards (with a small percentage of residents of some European countries) who are in the countries of their birth and permanent residence; (2) 38 migrants from different countries of the world (mainly from Europe and Latin America) living in Spain at the time of the survey. 87 respondents were women and 116 were men. Seventy-eight percent $(78.3 \%)$ of all the foreigners we interviewed belonged to the age category of 41 to 70 years and $19.7 \%$ to the category of 18 to 40 years.

When forming the target sample, the authors used random selection of respondents in the study group-strata. Identification of respondents with regard to their status as belonging to native or migrant groups was based on the results of the respondents' response to the questions about their location (in their own country or in the country of their permanent residence as a migrant, less than 5 years or more than 5 years). Respondents were identified as belonging to a group of Russianspeaking or participants from another cultures based on the language principle.

\section{Procedure}

Our main research method was a survey comprised of a specially prepared questionnaire, which was developed on the basis of our experience and the results of our previous study. The questionnaires were distributed in four European languages (Spanish, English, German, and Russian) using Google Forms. During statistical processing, we used the method of frequency analysis using contingency tables and a chi-square criterion, as well as a qualitative content analysis of statements respondents made on their attitudes towards the pandemic. 
The survey was conducted in the google-form (from the south of Spain, the city of Marbella, where the one of the authors also lives as a migrant). In total, residents and migrants from 24 countries answered the questionnaire. All subjects had a secondary or higher education. The professional composition of the respondents, as well as the degree of their employment at the time of the survey, was very diverse.

This article presents the results of a comparative analysis of the data of four groups of respondents: 1) Russian-speaking respondents living in their own countries, 2) Russian-speaking respondents-migrants, 3) European respondents living in their own countries (mostly residents of Spain), and 4) migrant respondents from different countries (non Russian-speaking).

\section{Results}

\section{The Impact of Cultural Factors on the Pandemic Experience}

The results revealed a number of positions on which the opinions of representatives of all four groups were almost identical (see Table 1).

Table 1

The proximity of the opinions of different groups of respondents*

\begin{tabular}{lcccc}
\hline \multicolumn{1}{c}{ Types of Statements } & $\begin{array}{c}\text { in their own } \\
\text { countries } \\
\text { (\%) }\end{array}$ & $\begin{array}{c}\text { Russian- } \\
\text { migrants }\end{array}$ & $\begin{array}{c}\text { Europeans } \\
\text { in their own } \\
\text { countries } \\
\text { (\%) }\end{array}$ & $\begin{array}{c}\text { Other } \\
\text { migrants } \\
\text { (\%) }\end{array}$ \\
\hline $\begin{array}{l}\text { In your opinion effective control of pande- } \\
\text { mic is a result of reasonable cooperation be- } \\
\text { tween citizens and authorities }\end{array}$ & 90 & 90 & 90 & 92 \\
$\begin{array}{l}\text { The control of the pandemic is a responsibil- } \\
\text { ity of all the states and people without excep- } \\
\text { tion, regardless of their national identity }\end{array}$ & 86 & 86 & 92 & 89 \\
$\begin{array}{l}\text { Which feeling prevails in you with regards to } \\
\text { the ongoing situation? Anxiety, nervousness }\end{array}$ & 40 & 37 & 31 & 40 \\
$\begin{array}{l}\text { What makes you happy about the ongoing } \\
\text { situation? Nothing makes me happy }\end{array}$ & 30 & 28 & 38 & 30 \\
$\begin{array}{l}\text { What makes you happy about the ongoing } \\
\text { situation? A possibility to be with family or } \\
\text { those close to you }\end{array}$ & 27 & 24 & 27 & 22 \\
$\begin{array}{l}\text { Frequent mentions of fatal casualties due to } \\
\text { coronavirus and images of funeral convoys: } \\
\text { try not to think about it }\end{array}$ & 28 & 28 & 22 & 22 \\
\hline
\end{tabular}

Note. ${ }^{\star}$ The differences are statistically insignificant

Regardless of status and nationality, almost all respondents agreed on the need for cooperation between an individual and the state, and universal international responsibility in overcoming the pandemic. Approximately the same percentage 
of respondents from different countries tried to avoid thoughts of death, but frequently mentioned deaths from coronavirus infection. The universal mood of most respondents was anxiety; a third of all subjects admitted that they found no reason for positive emotions in the pandemic situation, in contrast to a quarter of the survey participants who said they enjoyed the opportunity to be together with their families or loved ones.

While a convergence of opinions among migrants and the native population of the various countries of origin was revealed on a number of statements, at the statistical level there were differences $(\mathrm{p}<0.005$ and $\mathrm{p}<0.001)$ between the responses of groups of Europeans, and respondents from Russia and the post-Soviet space (see Table 2).

Table 2

Positions that revealed differences between representatives of the Russian-speaking sample and other foreign respondents, with a relative coincidence of opinions at the intergroup level

\begin{tabular}{|c|c|c|c|c|}
\hline Types of Statements & $\begin{array}{l}\text { Russians in } \\
\text { their own } \\
\text { countries } \\
(\%)\end{array}$ & $\begin{array}{l}\text { Russian- } \\
\text { migrants } \\
(\%)\end{array}$ & $\begin{array}{l}\text { Europeans } \\
\text { in their own } \\
\text { countries } \\
(\%)\end{array}$ & $\begin{array}{l}\text { Other } \\
\text { migrants } \\
(\%)\end{array}$ \\
\hline \multicolumn{5}{|l|}{ Attitude towards dissent regarding COVID-19 } \\
\hline $\begin{array}{l}\text { Information about the absence of emergency } \\
\text { measures and scarce control of the pandemic } \\
\text { in one or another country incurs in you: An- } \\
\text { ger and indignation }{ }^{\star *}\end{array}$ & 48 & 50 & 89 & 72 \\
\hline $\begin{array}{l}\text { Information about the absence of emergency } \\
\text { measures and scarce control of pandemic } \\
\text { in one or another country incurs in you: It's } \\
\text { their right; they should know what to do }\end{array}$ & 43 & 44 & 8 & 19 \\
\hline \multicolumn{5}{|l|}{ Patriotism level } \\
\hline $\begin{array}{l}\text { Do you feel more at ease than before with the } \\
\text { involvement and measures your country has } \\
\text { taken during this state of emergency? Yes }{ }^{* *}\end{array}$ & 35 & 45 & 71 & 69 \\
\hline \multicolumn{5}{|l|}{ Personal pandemic crisis } \\
\hline $\begin{array}{l}\text { Can you say that after the state of emergen- } \\
\text { cy due to the coronavirus spread, that you've } \\
\text { been suffering a personal crisis? Yes }\end{array}$ & 19 & 28 & 9 & 8 \\
\hline \multicolumn{5}{|l|}{ Preventative measures } \\
\hline $\begin{array}{l}\text { What preventive measures have you taken in } \\
\text { order to avoid infection? Self-isolation* }\end{array}$ & 45 & 51 & 38 & 28 \\
\hline $\begin{array}{l}\text { What preventive measures have you taken in } \\
\text { order to avoid infection? Absence of direct } \\
\text { contact with people outside your self-isola- } \\
\text { tion area* }^{*}\end{array}$ & 17 & 19 & 23 & 36 \\
\hline
\end{tabular}




\begin{tabular}{|c|c|c|c|c|}
\hline Types of Statements & $\begin{array}{l}\text { Russians in } \\
\text { their own } \\
\text { countries } \\
(\%)\end{array}$ & $\begin{array}{l}\text { Russian- } \\
\text { migrants } \\
\quad(\%)\end{array}$ & $\begin{array}{l}\text { Europeans } \\
\text { in their own } \\
\text { countries } \\
(\%)\end{array}$ & $\begin{array}{l}\text { Other } \\
\text { migrants } \\
(\%)\end{array}$ \\
\hline \multicolumn{5}{|l|}{ Willingness to change } \\
\hline $\begin{array}{l}\text { Given the impossibility of working or carry- } \\
\text { ing out your usual routines at present, how } \\
\text { do you take advantage of this confinement? } \\
\text { Do you contemplate the possibility of pivotal } \\
\text { change of your activity after the quarantine }\end{array}$ & 5 & 6 & 30 & 50 \\
\hline \multicolumn{5}{|l|}{ Pandemic deficiency } \\
\hline $\begin{array}{l}\text { What do you miss the most in the ongoing } \\
\text { situation? Friends and family**}\end{array}$ & 8 & 11 & 32 & 17 \\
\hline $\begin{array}{l}\text { What do you miss the most in the ongoing } \\
\text { situation? Work }\end{array}$ & 10 & 10 & 21 & 20 \\
\hline $\begin{array}{l}\text { What do you miss the most in the ongoing } \\
\text { situation? I am fully served }\end{array}$ & 13 & 9 & 4 & 3 \\
\hline \multicolumn{5}{|l|}{ Coping strategies } \\
\hline $\begin{array}{l}\text { What are you doing during the period of } \\
\text { forced self-isolation? Useful things }\end{array}$ & 37 & 35 & 29 & 28 \\
\hline $\begin{array}{l}\text { Given the impossibility of working or carry- } \\
\text { ing out your usual routines at present, how } \\
\text { do you take advantage of this confinement? } \\
\text { You use the current moment to learn some- } \\
\text { thing new }\end{array}$ & 38 & 41 & 3 & 14 \\
\hline $\begin{array}{l}\text { What are you doing during the period of } \\
\text { forced self-isolation? Trying somehow to kill } \\
\text { time* }\end{array}$ & 7 & 8 & 16 & 14 \\
\hline $\begin{array}{l}\text { What helps you cope with the stress caused } \\
\text { by the state of emergency? Belief in God }\end{array}$ & 12 & 10 & 8 & 7 \\
\hline $\begin{array}{l}\text { What helps you cope with the stress caused } \\
\text { by the state of emergency? Information re- } \\
\text { ceived from authorities and mass media* }\end{array}$ & 2 & 3 & 7 & 11 \\
\hline \multicolumn{5}{|l|}{ Involvement in the informational field } \\
\hline $\begin{array}{l}\text { How often do you watch the news? I don't } \\
\text { watch the news* }\end{array}$ & 13 & 12 & 5 & 6 \\
\hline \multicolumn{5}{|l|}{ Hopes and forecasts } \\
\hline $\begin{array}{l}\text { In your opinion, on a day like today a year } \\
\text { from now: Coronavirus will be left behind, } \\
\text { remembered with a smile ; life will return to } \\
\text { its usual course }{ }^{* *}\end{array}$ & 18 & 15 & 0 & 0 \\
\hline
\end{tabular}

Note. ${ }^{*}$ - differences are statistically significant $(p \leq 0.05):{ }^{* *}$ - differences are statistically significant $(p \leq 0.01)$ 


\section{The Impact of Migrant Status on Experiencing the Pandemic}

Particularly noteworthy were those question on which the opinions of the migrant groups tended to coincide or come close, and the opinions of representatives of groups people native to a country did not (see Table 3).

\section{Table 3}

Positions on which there was a tendency to a coincidence or convergence of opinions between Russian-speaking and foreign migrants

\begin{tabular}{|c|c|c|c|c|}
\hline Types of Statements & $\begin{array}{l}\text { Russians in } \\
\text { their own } \\
\text { countries } \\
(\%)\end{array}$ & $\begin{array}{l}\text { Rus- } \\
\text { sian-mi- } \\
\text { grants } \\
(\%)\end{array}$ & $\begin{array}{l}\text { Europeans } \\
\text { in their } \\
\text { own coun- } \\
\text { tries }(\%)\end{array}$ & $\begin{array}{l}\text { Other } \\
\text { migrants } \\
(\%)\end{array}$ \\
\hline \multicolumn{5}{|l|}{ Attitude toward violators of the emergency } \\
\hline $\begin{array}{l}\text { People who violate the quarantine bring } \\
\text { out in you: Irritation and anger**}\end{array}$ & 56 & 53 & 84 & 58 \\
\hline $\begin{array}{l}\text { People who violate the quarantine bring } \\
\text { out in you: I don't care what others do, if it } \\
\text { doesn't affect me directly }\end{array}$ & 15 & 21 & 8 & 15 \\
\hline $\begin{array}{l}\text { People who violate the quarantine bring } \\
\text { out in you: sympathy to their wish of not } \\
\text { wanting to be locked up indoors** }\end{array}$ & 30 & 26 & 8 & 27 \\
\hline \multicolumn{5}{|l|}{$\begin{array}{l}\text { Relationships with close people during } \\
\text { the pandemic }\end{array}$} \\
\hline $\begin{array}{l}\text { After the state of emergency due to the co- } \\
\text { ronavirus spread, your relations with your } \\
\text { loved ones have suffered no change }\end{array}$ & 72 & 51 & 56 & 47 \\
\hline $\begin{array}{l}\text { After the state of emergency due to the co- } \\
\text { ronavirus spread, your relations with your } \\
\text { loved ones have deepened }\end{array}$ & 14 & 33 & 32 & 47 \\
\hline $\begin{array}{l}\text { How do you satisfy your needs to commu- } \\
\text { nicate during the period of self-isolation? } \\
\text { Through private correspondence in mo- } \\
\text { bile applications or e-mails* }\end{array}$ & 17 & 27 & 25 & 39 \\
\hline $\begin{array}{l}\text { How do you satisfy your needs to commu- } \\
\text { nicate during the period of self-isolation? } \\
\text { By telephone } e^{\star *}\end{array}$ & 58 & 48 & 30 & 25 \\
\hline $\begin{array}{l}\text { Do you abide by the coronavirus preven- } \\
\text { tion instructions? Yes, because it can keep } \\
\text { my loved ones safe from infection }\end{array}$ & 44 & 48 & 55 & 64 \\
\hline \multicolumn{5}{|l|}{ Mood during the pandemic } \\
\hline $\begin{array}{l}\text { Which feeling prevails in you with regards } \\
\text { to the ongoing situation? State of calm }\end{array}$ & 34 & 40 & 34 & 40 \\
\hline $\begin{array}{l}\text { What worries you the most in the ongoing } \\
\text { situation? The situation of uncertainty }\end{array}$ & 25 & 38 & 31 & 50 \\
\hline
\end{tabular}




\begin{tabular}{|c|c|c|c|c|}
\hline Types of Statements & $\begin{array}{l}\text { Russians in } \\
\text { their own } \\
\text { countries } \\
(\%)\end{array}$ & $\begin{array}{l}\text { Rus- } \\
\text { sian-mi- } \\
\text { grants } \\
(\%)\end{array}$ & $\begin{array}{l}\text { Europeans } \\
\text { in their } \\
\text { own coun- } \\
\text { tries }(\%)\end{array}$ & $\begin{array}{l}\text { Other } \\
\text { migrants } \\
(\%)\end{array}$ \\
\hline $\begin{array}{l}\text { The uncertainty of the current state of } \\
\text { emergency does not allow me to organize } \\
\text { my life as I would like to: Yes }\end{array}$ & 70 & 79 & 66 & 72 \\
\hline $\begin{array}{l}\text { Which feeling prevails in you with regards } \\
\text { to the ongoing situation? Spite, impotence, } \\
\text { wrath }\end{array}$ & 7 & 6 & 16 & 3 \\
\hline \multicolumn{5}{|l|}{ Preventative measures } \\
\hline $\begin{array}{l}\text { What preventive measures have you taken } \\
\text { in order to avoid infection? Measures to } \\
\text { enhance personal immunity (sports activi- } \\
\text { ties, showering with cold water, etc.)* }\end{array}$ & 6 & 13 & 5 & 11 \\
\hline $\begin{array}{l}\text { What preventive measures have you taken } \\
\text { in order to avoid infection? Tightened in- } \\
\text { dividual hygiene measures** }\end{array}$ & 27 & 10 & 32 & 22 \\
\hline \multicolumn{5}{|l|}{ Coping strategies } \\
\hline $\begin{array}{l}\text { What helps you cope with the stress caused } \\
\text { by the state of emergency? Belief in myself }\end{array}$ & 8 & 10 & 4 & 8 \\
\hline $\begin{array}{l}\text { What helps you cope with the stress caused } \\
\text { by the state of emergency? Belief in a posi- } \\
\text { tive outcome whichever way the situation } \\
\text { turns }\end{array}$ & 40 & 45 & 23 & 33 \\
\hline $\begin{array}{l}\text { What helps you cope with the stress cau- } \\
\text { sed by the state of emergency? Family sup- } \\
\text { port }{ }^{\star \star}\end{array}$ & 17 & 14 & 38 & 25 \\
\hline $\begin{array}{l}\text { What are you doing during the period of } \\
\text { forced self-isolation? Personal growth and } \\
\text { self-improvement* }\end{array}$ & 8 & 15 & 8 & 17 \\
\hline \multicolumn{5}{|l|}{ Involvement in the informational field } \\
\hline $\begin{array}{l}\text { How often do you watch the news? A few } \\
\text { times per day }\end{array}$ & 32 & 27 & 46 & 39 \\
\hline \multicolumn{5}{|l|}{ Willingness to change } \\
\hline $\begin{array}{l}\text { Given the impossibility of working or car- } \\
\text { rying out your usual routines at present, } \\
\text { how do you take advantage of this confine- } \\
\text { ment? You are ready to perform the work } \\
\text { that will be most in demand, even if it is } \\
\text { not to your liking }\end{array}$ & 8 & 13 & 22 & 29 \\
\hline $\begin{array}{l}\text { In the present state of emergency due to } \\
\text { the pandemic situation, are you ready to } \\
\text { take important decisions with regards to } \\
\text { yourself and your loved ones? Yes }\end{array}$ & 39 & 35 & 52 & 44 \\
\hline
\end{tabular}

${ }^{*}$ - differences are statistically significant $(p \leq 0.05) ;{ }^{* *}$ - differences are statistically significant $(p \leq 0.01)$ 


\section{Discussion}

\section{The Impact of Cultural Factors on the Pandemic Experience}

An analysis of the results allows us to note a number of cultural differences. Representatives of the different cultures evaluated the actions of those countries that are not actively fighting the pandemic much more negatively than the Russianspeaking respondents did. At the same time the Russian-speaking participants were of the opinion that each country is free to choose its own strategy for combating COVID-19. Respondents from different countries felt much more involved in the fate of their countries during the pandemic than the Russian speakers. Russianspeaking respondents took self-isolation as the main measure of preventing infection; in the rest of the sample this measure went along with refusing direct contacts with someone outside the quarantine zone.

The majority of Russian-speaking respondents used the period of self-isolation to learn something new and do useful things, and other (non-Russian speakers) participants were more focused on considering the possibility of a radical change in activity, were more likely to "kill time" during quarantine, and were more likely to miss their jobs. This part of respondents were more likely to lack friends and family during quarantine, while among Russian-speaking respondents, there was a higher percentage of those who, in their own words, did not feel a deficit in any area. Compared to others, a larger percentage of Russians admitted that they were experiencing a personal crisis during the pandemic, while some Russian-speaking respondents hoped that in a year, everything would be back to normal; among representatives of other cultures no one choose this option. At the same time, believing in a positive outcome of the situation helped the Russian-speaking respondents to cope with the difficult situation to a greater extent than the anothers.

European respondents and representatives of other cultures were characterized by a negative attitude towards dissent in the fight against a pandemic, an increase in the level of patriotism, and a willingness to maintain self-isolation and refuse contact with anyone outside the quarantine zones. The main resources for coping with stress were work and especially the family, which might indicate a clear or latent fear of death, given that "close relationships with other people perform a powerful defense function, including the defense from existential threats, primarily from the threat of the finiteness of existence" (Grishina, 2018). Representatives of this group had an increased readiness for an operational response to the situation through a cardinal change of activity.

The sample of Russian-speaking respondents reflected greater tolerance of the strategies of other countries regarding coronavirus, expressed the desire to wait out the pandemic, and chose self-isolation as the main preventive measure, seeing it as an opportunity to learn something new and to implement useful things. The waitand-see position was also manifested in the desire to return in a year to the usual way of life. Despite a higher percentage of respondents experiencing a personal crisis, the characteristic coping strategy for this group was an irrational belief that everything will be fine.

Such obvious differences in attitudes toward the pandemic can be partly explained by differences in the worldviews of the Western and Russian mentality. 
The format of this article does not allow for a detailed analysis of such a broad topic, but it is worth briefly mentioning the role of ideas of utilitarianism and hedonism in formation of modern Western values, as well as the special attitude of the Russian people toward suffering. Suffering, in accordance with the traditional Russian mentality, leads to inner development and reveals the truth of life (Golovanivskaya, 2019). In light of this worldview, a pandemic is much more likely to be perceived by Europeans as a tragedy, unlike the Russians, who can interpret it as experience.

When studying the context of a pandemic living in European countries and in the post-Soviet space, it is noteworthy that the national media compare the current crisis with various reference points in the history of various countries. Thus, in European countries, when describing the impact of the pandemic on a person, the social sphere, and the economy, there is a reference to the scale of the consequences of the Second World War (1941-1945) ("La Pandemia de Coronavirus...", 2020; "Coronavirus Pandemic Worst Crisis since Second World War...", 2020; "Coronavirus: la più grande recessione dal Dopoguerra?...”, 2020). In Spain, in addition, parallels are drawn with the Spanish Civil War (1936-1939) (Berdún, 2020; "De Guindos: España afronta la peor crisis económica desde la Guerra Civil...”, 2020). In the countries of Latin America, the United States, and China, comparisons are made with the consequences of the Great Depression (1929-1933) ("Coronavirus: Worst economic crisis since 1930s depression...", 2020; "Coronavirus Slump Is Worst Since Great Depression...", 2020). Moreover, in the countries of the postSoviet space, the comparison of the current crisis occurs with two main events: the collapse of the USSR (1991) and the accident at the Chernobyl nuclear power plant (1986) ("Kazakhstan is one step away from...", 2020; "Journalist: the current crisis...", 2020; Nosovich, 2020).

Thus, European and Western media are comparing the current situation with crises that took place 75 and 87 years ago, although there are very few eyewitnesses living today. But in the post-Soviet space, only representatives of generations born after 1995 do not have personal experience living in a powerful social and economic crisis (the period of "perestroika" after the collapse of the USSR). The rest of the adult population of the countries of the post-Soviet bloc has had personal experience in overcoming a large-scale crisis.

According to a recent study on the characteristics of anxiety during a pandemic by representatives of different age groups in Russia, "the youngest age group (18-24 years) is most vulnerable to the development of anxiety-phobic and depressive reactions. In the younger age group, the phobic components of anxiety predominate, while at the same time they are not associated with the fear of contracting infection. Their anxiety is probably a reaction to the general social uncertainty, since they had never experienced such crises before. Perhaps this is due to the fact that representatives of this generation were not faced, at a conscious age, with major crises across the country or around the world" (Kholodova, 2020). The researcher's conclusion suggests that the lack of experience with major crises among residents of Europe and Western countries correlates with a higher level of anxiety and tension, which was reflected in the responses by respondents. 


\section{The Impact of Migrant Status on Experiencing the Pandemic}

Migrants, regardless their ethnicity, were less irritated by quarantine violators than people native to a country, and were more likely to understand them; they were more often indifferent to the actions of other people that did not directly affect them. They had a calmer attitude than the native population did. Migrants paid more attention to strengthening their own immunity, compared with the people native to a country, and believed more in themselves.

Compared with the native population, migrants were more willing to perform any work that was in demand, even if they did not like it. They were less likely than people native to a country to seek family support. They were also distinguished from native representatives by a stronger belief that everything will be fine in the future. To a greater extent than the people native to a country, they took care to protect their families from infection and for the most part followed the instructions for this reason. Their relations with people they were close to became deeper during quarantine, and they realized their need for communication through individual contact by phone or via mobile applications, in contrast to group communication in social networks, which was more preferred by the native population.

Uncertainty worried migrants more than it did people native to a country and prevented them from organizing their lives. To a lesser extent than the native population, they were ready to make important decisions for themselves or loved ones during quarantine. But compared with the native population, migrants felt less powerless. They followed the news less often than the people native to a country and did not often use extra hygiene measures. But they were more active than the native people, strengthened their immunity, and were engaged in selfimprovement during quarantine.

The pandemic crisis has once again highlighted the enormous importance of the phenomenon of migration in today's world. "In the first decade of the 21st century, migration made a very significant contribution to the renewal of wealthy societies and, with a comprehensive assessment, this contribution will probably increase in the coming decades ... Thus, we are not talking about a marginal, residual and opportunistic phenomenon controlled by its transitivity, but, on the contrary, about the main and structural component of demographic, social and economic change" (Livi Bacci, 2012). At the same time, according to many researchers, today migrants are one of the most vulnerable segments of the population. "As in many other crises, migrants may be particularly vulnerable to the direct and indirect impacts of COVID-19.... Many countries have responded to COVID-19 with increased closures, tighter immigration regulations, and further marginalization of migrants." (Guadagno, 2020).

However, despite their increased vulnerability, migrants have adopted an active stance toward life, this time in the face of a pandemic. According to the previously mentioned study that we conducted in 2019 on a sample of 143 Russian-speaking and foreign migrants living in Spain, one of the most important vectors of choice in favor of migration is to avoid a difficult life situation. But if the situation in the country of migration becomes critically problematic, many migrants decide to reemigrate, that is, return to their home countries. Thus, according to some reports, tens of thousands of migrants from various countries have already returned to their 
countries, such as immigrants from Kyrgyzstan and Moldova, Morocco and Venezuela, Britain and Romania ("Millions of Migrants Return to... ", 2020; " Labor Migrants Return to... “, 2020; “ British Expats Head Home... “, 2020).

What helps migrants maintain the ability to remain "above the situation" in the face of a severe crisis? "... Cardinal breakdowns call into question not only life, but existence, the very existence of people in the world. Hence, apparently, the logical observation is that social crises are associated with personality crises, with questions about how to survive, about the meaning of existence. In the years of the break, as, for example, in Europe after the First World War, the relevant question was whether I will have a piece of bread, a roof over my head and any clothes in the cold.." (Grishina, 2019). The key concept in this context, in our opinion, is the presence of meaning that helps to overcome a difficult life situation. According to the ideas of Western authors, in particular P. Wong, the fear of death stems from the failure to find meaning in life, while the presence of meaning is associated not only with a positive attitude towards death, but also with psychological health (Bakanova \& Gorkovaya, 2014).

Regardless of motivation, at the heart of any decision to migrate there is an overriding goal, either short-term or long-term, which is related to the satisfaction of one's own needs or assistance to loved ones. It is the presence of this goal that helps all immigrants overcome the so-called migration crisis: complex, multi-stage, and time-stretched (Acholegui Loizate, 2009). It can be assumed that, as in the case of the experience of living in a large-scale national crisis, the experience of living in this migration crisis lays the foundation for increased stress resistance, flexibility, and adaptability of migrants to rapidly changing life contexts.

\section{Conclusion}

1. Common to all representatives of this study's international sample were the ideas of international cooperation and universal responsibility for overcoming the pandemic. Also common was an emotional backdrop saturated with a state of anxiety.

2. Cultural factors had a strong influence on the experience of the pandemic situation. Respondents from different countries (non-Russian speakers) were very intolerant of dissent in the fight against the pandemic in general and against those who violate prescribed sanitary measures, in particular. In the pandemic situation, representatives of this group showed an increase in patriotism. The main resources for coping with stress were work and family, and an increased readiness for an operational response to the situation through a change of activity. Fear of death was frequently expressed. Coping strategies were rational-external.

The sample of Russian-speaking respondents showed great tolerance to the positions of other countries regarding the coronavirus, as well as to the position of those who did not comply with the prescribed sanitary standards. They expressed a desire to wait out the pandemic and quickly return to the usual way of life. Their main preventive measure was self-isolation, which was considered an opportunity for the development of something new and the pursuit of useful things. Despite the higher percentage of respondents experiencing personal crises due to the pandemic, the irrational belief that everything would soon be fine was a characteristic 
strategy for coping with stress in this group. Their coping strategies were generally irrational-internal.

These differences may be due to 1) a difference in the ideological foundations of each group's mentality: a utilitarian-hedonistic one in the West versus the tradition of interpreting suffering as a stage of personality development in Russia, and 2) the recent collective experience of living under nationwide crisis conditions (collapse of the USSR) among Russian-speaking respondents versus the lack of such experience among European respondents.

3. The perception of the pandemic by migrants differed from the perception of the situation by the native population by showing greater internal balance, selfconfidence, confidence in a positive outcome, willingness to quickly respond to a new context, an internal locus of control, the ability to value life against the background of a deadly threat, and treating loved ones as a valuable resource and the object of care, instead of as a way to drown out a sense of alarm. Migrants were ready to take care of both relatives and themselves, and were interested not only in strengthening their immunity, but also in self-improvement. They were more tolerant of the opinions of other people. This position might be explained by their experience of the migration crisis, as well as their motivation for migrating, which reflected an orientation toward the meaning of life such as is necessary for successfully overcoming a crisis like this pandemic.

\section{References}

Achótegui Lozaite, J. (2009). Salud mental y migración. El síndrome del inmigrante. In Sánchez Vázquez, J.F. (Ed.), Psicología e immigración (pp. 35-64). Salamanca: Publicaciones Universidad Pontíficia de Salamanca.

Bakanova, A.A. \& Gorkovaya, I.A. (2014). Psikhologiia strakha smerti: teoriia i praktika [Psychology of death fear: theory and practice]. Saint Petersburg: Izdatel'stvo RGPU im. Gertsena.

Berdún, D.R. (2020, April, 11). Paralelismos bélicos: la crisis del coronavirus y la Guerra Civil. The Conversation. Retrieved from https://theconversation.com/amp/paralelismos-belicos-la-crisisdel-coronavirus-y-la-guerra-civil-135912

British expats head home as pandemic hits UAE economy. (2020, June, 27). Anadolu Agency (AA). Retrieved from https://www.aa.com.tr/en/latest-on-coronavirus-outbreak/british-expats-headhome-as-pandemic-hits-uae-economy/1892295

Coronavirus pandemic worst crisis since Second World War, says UN chief. (2020, April, 1). Independent. Retrieved from https://www.independent.co.uk/news/world/coronavirus-pandemic-crisisww2-united-nations-antonio-guterres-a9440006.html

Coronavirus: Worst economic crisis since 1930s depression, IMF says. (2020, April, 9). BBC. Retrieved from https://www.bbc.com/news/business-52236936

De Guindos: España afronta la peor crisis económica desde la Guerra Civil. (2020, April, 12). Expansión. Retrieved from https://amp.expansion.com/economia/2020/04/12/5e92fa72e5fdea27668b4 56d.html

Golovanivskaya, M. (2019). Osnovy evropeiskogo mirovozzreniia po dannym iazyka. Nekotorye bazovye kontsepty $v$ predstavlenii frantsuzov $i$ russkikh [Fundamentals of the European worldview according to language. Some basic concepts in the representations of the French and the Russians]. Moscow: Izdatel'skie resheniia [Publishing solutions].

Grishina, N.V. (Ed.). (2019). Psikhologiia lichnosti: Prebyvanie v izmenenii [Psychology of Personality: Being in Change]. Saint Petersburg: Izdatel'stvo Sankt-Peterburgskogo universiteta [Publishing house of SPBGU]. 
Grishina, N.V. (2018). Ekzistentsial'naia psikhologiia [Existential Psychology]. Saint Petersburg: Izdatel'stvo Sankt-Peterburgskogo universiteta [Publishing house of SPBGU].

Guadagno, L. (2020). Migrants and the COVID-19 pandemic: An initial analysis. International Organization for Migration (IOM), 60, 2-25.

Journalist: the current crisis will hit harder than 2008 and the collapse of the USSR. (2020, March, 18). Mixnews. Retrieved from https://mixnews.lv/latviya/2020/03/18/zhurnalist-nyneshnij-krizisudarit-silnee-2008-goda-i-raspada-sssr/amp/

Kazakhstan is one step away from the deepest crisis since the collapse of the USSR. (2020, May, 6). Forbes Kazakhstan. Retrieved from https://forbes.kz//process/expertise/vliyanie_covid-19_na_ klyuchevyie_sektora_ekonomiki_kazahstana?

Kholodova, Yu.B. (2020). Osobennosti perezhivaniia trevogi v period pandemii COVID-19 predstaviteliami raznykh vozrastnykh grupp [Features of anxiety experience during the pandemic with COVID-19 representatives of different age groups]. Mezhdunarodnyi zhurnal meditsiny $i$ psikhologii / International Journal of Medicine and Psychology, 3(2), 114-117

Labor migrants return to Moldova because of COVID-19, but no one is happy with them. (2020, April, 9). Deutsche Welle (DW). Retrieved from https://bit.ly/3m8pNoJ

La pandemia de coronavirus es la mayor crisis del mundo desde la II Guerra Mundial, dice la ONU. (2020, April, 01). Euronews. Retrieved from https://es.euronews.com/2020/04/01/la-pandemiade-coronavirus-es-la-mayor-crisis-del-mundo-desde-la-ii-guerra-mundial-dice-la

Livi Bacci, M. (2012). Breve historia de las migraciones. Madrid: Alianza.

Lupulyak, P. \& Grishina, N.V. (2020). Faktory negativnogo samooshchushcheniia migranta v novoi strane [Factors of negative self-perception of a migrant in a new country]. Vestnik Sankt-Peterburgskogo Universiteta. Psychologiya [Saint Petersburg University Psychology Bulletin], 2, 128141. https://doi.org/10.21638/spbu16.2020.202

Más de 33.000 migrantes venezolanos en Colombia regresan a su país por el coronavirus. (2020, April, 14). Europa Press. Retrieved from https://amp.europapress.es/internacional/noticia-mas33000-migrantes-venezolanos-colombia-regresan-pais-coronavirus-20200414113656.html

Migration. In United Nations (UN). Retrieved from https://www.un.org/en/sections/issues-depth/ migration/index.html

Millions of migrants return home due to coronavirus in Eastern Europe. (2020, May, 13). Red Spring News Agency. Retrieved from https://rossaprimavera.ru/news/fa75a6b5

Nosovich, A. (2020, March, 20). The coronavirus will be to NATO and the EU what Chernobyl was to the Soviet Union. Rubaltic. Retrieved from https://www.rubaltic.ru/article/politika-iobshchestvo/20032020-koronavirus-stanet-dlya-nato-i-es-tem-zhe-chem-stal-dlya-sovetskogosoyuza-chernobyl/?amp=Y

Stefanenko, T. (2014) Etnopsychologia [Ethnopsychology]. Moscow: Aspent Press.

Coronavirus: la più grande recessione dal Dopoguerra? (2020, June, 25). Swissinfo. Retrieved from https://www.swissinfo.ch/ita/previsioni-congiunturali_coronavirus--la-pi\%C3\%B9-grande-recessione-dal-dopoguerra-/45844320

Zumbrun, J. (2020, May, 10). Coronavirus Slump Is Worst Since Great Depression. Will It Be as Painful? The Wall Street Journal. Retrieved from https://www.wsj.com/articles/coronavirus-slump-isworst-since-great-depression-will-it-be-as-painful-11589115601

Original manuscript received July 27, 2020

Revised manuscript accepted November 20, 2020

First published online December 30, 2020

To cite this article: Grishina, N.V., Lupulyak, P.V. (2020). The COVID-19 Experience: Features of Culture and Belonging in the Context of Peoples Native to a Country and Migrants. Psychology in Russia: State of the Art, 13(4), 119-133. DOI: 10.11621/pir.2020.0408 